\title{
THE LENGTH AND PLURALITY OF SUPREME COURT OF CANADA DECISIONS
}

\author{
THE HONOURABLE CLAIRE L'HEUREUX-DUBE*
}

\begin{abstract}
Madame Justice L'Heureux-Dubé discusses how the length and plurality of judicial opinions emanating from the Supreme Court of Canada are manifestations of the justices' "judicial functions" as both adjudicators and educators. After a thoughtful look at the history and background of the dual aspect of the judicial role, Her Ladyship responds to critics of the Court's decision-making style by concluding that long and complex judgments are the exception rather than the rule, that such judgments are often a necessary step in the development of the law, and that adjustments to the process may only be achieved by the cooperation of all members of the legal community.
\end{abstract}

\begin{abstract}
Madame le juge L'Heureux-Dubé étudie comment la longueur et la pluralite des opinions judiciaires émanant de la Cour suprême du Canada sont représentatives des "fonctions judiciaires", les juges étant a la fois arbitres et éducateurs. Après avoir suivi attentivement l'histoire de ce double aspect du rôle judiciaire, l'auteur répond aux critiques qui attaquent le processus décisionnel suivi par la Cour en concluant que les jugements longs et complexes sont l'exception plutôt que la règle, qu'ils constituent une étape nécessaire d̀ l'évolution de la loi, et que la démarche ne peut être modifiée qu'avec la coopération de tous les membres de la communauté juridique.
\end{abstract}

\section{TABLE OF CONTENTS}

I. INTRODUCTION $\ldots \ldots \ldots \ldots \ldots \ldots \ldots \ldots \ldots \ldots \ldots, 581$

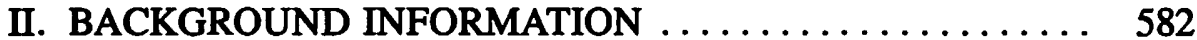

III. HISTORICAL COMPARISONS AND CONTRASTS $\ldots \ldots \ldots \quad 583$

IV. THE DUALITY OF JUDICIAL FUNCTIONS: EDUCATORS AND DECISION-MAKERS .......... 585

V. CONCLUSIONS $\ldots \ldots \ldots \ldots \ldots \ldots \ldots \ldots \ldots \ldots \ldots, 587$

\section{INTRODUCTION}

There has been a lot of talk these last few years about the courts' enhanced role, and in particular the Supreme Court's new importance as the watchdog of Parliament's legislative activities. Often we hear journalists rave about a "government of judges" that has taken over the country; an insidious power held by nine unknowns, half-gods or demons, for whom no one voted and who are difficult to remove from office.

Their argument proceeds as follows: The Charter ${ }^{1}$ makes it illegal for governments to infringe upon certain personal rights and freedoms. The Supreme Court of Canada now has the final word in determining just what those rights and freedoms are. Therefore, the Supreme Court is in fact making the law, rather than Parliament or the provincial legislatures. What worries our critics is that justices are appointed and not elected and, in a democracy, lawmaking should be left to elected representatives. ${ }^{2}$

* Puisne Judge, Supreme Court of Canada.

1. Canadian Charter of Rights and Freedoms, Part I of the Constitution Act, 1982, being Schedule B of the Canada Act, 1982 (U.K.), 1982, c.11.

2. In faimess to the legitimate criticisms of "judicial policy-making", courts do face some institutional weaknesses in dealing with policy questions. See D.L. Horowitz, The Courts and Social Policy (Wash., D.C.: The Brookings Institution, 1977). 
I believe that it is extremely important for all of us, judges, lawyers, and the public at large, that this image of the Court's evil powers be dissipated. Since the judicial system exists only for them, and because of them, the citizens of this country must know and understand that towards which they pay so much money. After all, lawyers are educated at the public's expense, and the judiciary is financed by the public purse; therefore, the public has a right to expect a fair return on its investment. Equally, the public requires a greater understanding of the real purpose and function of the Courts.

Since the constitutional amendments of 1982, Charter arguments have often been used as shortcuts to change the system - a more direct means than legislative action, by which individuals can rarely act themselves. The courts, however, are not always the best forum in which to settle political issues, and these attempts to promote political agendas through the courts are sometimes analogous to attempts to cure a headache with brain surgery.

As much as it has affected the Court's role, I believe that the Charter has changed the Canadian public's perception of its judicial system and of the Supreme Court. While probably not as "flamboyant" as the Supreme Court of the United States, the Supreme Court of Canada was placed under the spotlight by the Charter, and its work is now more closely scrutinized by the public than it has ever been in the past.

\section{BACKGROUND INFORMATION}

The attention given to the Court since the advent of the Charter, when combined with the importance of public awareness of what it is that the court does, neatly leads to the main topic of this paper, namely, the length and plurality of the written opinions of our Supreme Court.

It would be appropriate here to discuss the process of drafting an opinion. When all goes very well in a particular appeal, a single opinion of twenty or twenty-five typewritten pages may be all that is required. In an ideal world, a judge can get the opinion ready after only one or two preliminary drafts, that is, fourty or fifty typewritten pages later. On the day of release, the Court makes roughly 300 copies of the judgment, printed on double-sided paper, thus bringing the number of pages to somewhere between 12,000 and 15,000 typewritten pages for this one particular appeal. Remember that the Supreme Court renders approximately 100 written opinions per year, 138 in 1988, and so the total climbs to nearly one and a half million pages.

Now, not every appeal is dealt with in a single, twenty to twenty-five typewritten page opinion. The drafts are generally preceded by many internal memoranda, and it is not unusual for some of the justices to circulate amendments to preliminary drafts. It can happen that a judge will become so involved in writing the opinion that he or she will produce an opinion ranging from fifty to one hundred pages in length. Furthermore, sometimes a decision is not unanimous, and a dissent must be prepared. Even where the result is unanimous some judges may feel that it is necessary for them to write separate reasons.

The amount of paper consumed annually in this process is measured in tons. Last year alone the Supreme Court sent thirty-four tons of paper for recycling. 
That, I am advised, is the amount of paper which can be produced by 600 trees. Given this quantity of paper sent for recycling, one could only guess how many tons of paper are consumed to produce all the pages the Court actually uses. One might think, in reaction to these figures, that the living tree of the Constitution is growing at the expense of the living trees in our forests!

After the efforts noted above are completed, the Court is then subjected to criticisms emanating from every branch in our legal community. Some counsel express dismay at the prospect of reading voluminous decisions. They wonder why the Court writes one hundred pages when the ratio fits in a single paragraph. In the law faculties, professors never use the full text of our decisions in their casebooks. Instead, they spend entire summers cutting and pasting photocopies of the law reports. Would it not be a better use of our country's legal minds to put pens in their hands rather than scissors and glue sticks? Finally, in recent case comments, the Supreme Court has been referred to as a "fractious" Court plagued by "deadlock and confusion". Surely, this is not the type of direction which judges and the community at large are entitled to expect from the highest court in the land.

The individuals on the Court are acutely aware of the fact that some of the judgments rendered are lengthy, and that this is further complicated by numerous individual opinions which lead to a plurality of judgments. In 1988, half of the Court's written judgments contained more than a single opinion. A judicious course, then, is to put things in perspective, and to then ask where the problem finds its source and how it can be remedied. I do not pretend to offer a cure to the problem, but I am confident that everyone can benefit from the discussion of these questions. If for no other reason, the benefit will arise because a healthy relationship among the Supreme Court, the lower courts, the universities and the profession is a crucial element of the administration of justice, and the discussion which ensues will help to contribute to such a relationship.

\section{HISTORICAL COMPARISONS AND CONTRASTS}

Putting matters in perspective, whatever the final verdict, the first observation is that the Court cannot be as bad as it used to be. Back in 1877, when the Court first began to sit, its six judges would more often than not render their judgments orally. Sometimes they prepared personal notes, sometimes not. Each read out loud, starting with the Chief Justice, and then the puisne judges followed suit, ultimately in descending order of seniority. There was generally no effort to coordinate the judgments read by the judges. Each judge summarized in his speech the facts which he felt were material. The Court reporter took everything down, faithfully transcribing the judge's speeches.

The printed result often partook of a disaster. Just to get a complete picture of the facts, the reader had to consult every individual opinion. There was overlap and contradiction between each individual account of the material facts. To get a clear idea of the law resulting from the case could be an even more challenging endeavour. Individual opinions were usually given with no reference to the conclusions previously given by the other members of the Court. 
Additional, often repetitive, reasons were given by all the judges sitting on a case.

Sometimes, when a particularly interesting case came up, the judges would prepare lengthier, written opinions. There existed no systematic policy of court conferences back then. Each judge went into a little retreat in his office to prepare his written opinion in isolation. There was no tradition or court policy regarding the exchange of views at that time. This lack of collegiality did not help to solve the problem of repetition in the written judgments. Thus, in the most important cases the problems of repetition and overlap encountered in the other cases were amplified, not resolved.

The situation in Canada contrasted sharply with the American system at that time. By 1800 , the Supreme Court of the United States had already committed itself to issuing what is still called today the "opinion of the Court". Initially, these were the reasons which all members of the Court adopted. Individuals subsumed their own differences of opinion and endorsed the "opinion of the Court"'. While there soon appeared an occasional dissenting opinion, throughout the nineteenth century dissents remained the exception. The policy was to deliver one opinion per judgment.

As a result, in 1900, in contrast to written opinions of the Supreme Court of Canada, which typically were a complex amalgam of individual pronouncements, the American equivalent was a clear and forceful collective effort.

As years went by, however, the American way gradually eroded. The growing judicial attachment to dissents gave renewed value to individual opinions, and American judges began to deliver separate reasons more often. The great American dissenters brought in their wake a message of encouragement for those who wished to express their views separate from the "opinion of the Court". In time, more dissenting judges wrote additional dissenting reasons. There even appeared separate concurring opinions, something which would have been impossible to imagine 100 years earlier.

In Canada, in the early 1900's, a different development began. Court observers and the profession began voicing their dissatisfaction with the Court's written judgments. When the time was ripe for reform, in the mid-1920's, Chief Justice Anglin assumed a key role in reshaping Canadian judicial opinions. Speaking to the members of the Canadian Bar Association in 1925, he delivered the following message:

Before I became Chief Justice of Canada, comment was almost universal that Supreme Court judgments were entirely too numerous. Each volume was filled with repetitions of facts covering the same ground. There were usually judgments delivered by every member of the Court, many of them simply restatements of what had been said perhaps better by somebody else. That was the situation with which I was called upon to deal. It occurred to me the remedy was this: to suggest to my colleagues that, wherever possible, we should agree that the majority should deliver one judgment, the judgment of the Court, from which would be eliminated all side issues on which every member of the Court was not prepared to concur, and in which there would be a simple, plain statement of material facts, so that a perusal of the one judgment would enable anybody reading it to know exactly what the Court had decided without having to study the opinions of half a dozen gentlemen in order to find some point on which possibly they agreed, while they differed in a good many others.

In the years that followed, the Court remained attached to the policy set by Chief Justice Anglin. And for a number of years the Court did quite well. 
Seriatim opinions were all but abandoned and the Court's opinions in the years 1930 to 1950 were mostly expressed in a judgment of the Court, or when unanimity was impossible, in one judgment of the majority and one of the minority. The facts and procedural background were neatly summarized in a single opinion and in this respect, at least, overlap and contradiction were eliminated. The presence of a single opinion, or, occasionally, of a single majority opinion accompanied by a single dissenting opinion, brought clarity to the law. Progress culminated in the 1960's, when Court conferences became systematic under Chief Justice Cartwright. One can appreciate what beneficial effect prior communication can have on the clarity of opinions.

By the mid 1960's, a complete turnabout had occurred. The Supreme Court of Canada rendered clear and forceful pronouncements, while the American Supreme Court was faced with divisiveness and plurality. This is one area where Canadians were half a century ahead of their neighbours!

This brief account of the general background, however, is meant neither to throw the blame on our predecessors, nor to obscure the fact that there are still problems today for which we are solely accountable. I now propose to turn to the reasons for such a situation.

\section{THE DUALITY OF JUDICIAL FUNCTIONS: EDUCATORS AND DECISION-MAKERS}

Why are written opinions occasionally so lengthy and numerous? The answer lies in the role which the judges set for themselves. It is easy to sit back and vote; it is another matter to write pursuasive reasons that will gather support for the conclusion; and it is yet more difficult to render justice while at the same time helping to shape the law of tomorrow. If reasons are written for the parties involved in the litigation, they are also useful for the community at large, especially when those reasons emanate from the Supreme Court of Canada. For better or for worse, Supreme Court judgments are an important feature of legal education as well as directives to lawyers and judges alike and, of course, to citizens of this country. Supreme Court Justices are teachers and should be leaders in the field of law as well as decision-makers.

These two aspects of our judicial role sometimes lead to friction and cause length and divisiveness in our written opinions. The advent of the Charter has, of course, only increased the possibility of such friction.

This is not to say that lengthy judgments, or judgments containing a plurality of opinions, are failures; quite the contrary. When a particular case presents the Court with an opportunity to give definite direction on a particular point of law, the natural inclination is to explore each facet of the particular legal problem, recount history and account for each theory or precedent. In this sense, a lengthy judgment can mean success in the pedagogical aspect of the enterprise. One needs only to think of monuments such as $R$. v. Big M Drug Mart, ${ }^{3}$ written by Chief Justice Dickson, and Rafuse v. Central Trust ${ }^{4}$ by Justice Le Dain. Each of these spans 70 pages of the Supreme Court Reports. But who 
can claim that these lengthy judicial pronouncements are anything but forceful and persuasive?

One should not scoff at the pedagogical function of judgments. The Court as an institution was not always concerned with the advancement of the understanding of the law. In their judgments up until the 1930's, judges of the Supreme Court focussed almost exclusively on their role as decision-makers. Judges today know the value of a university education in the law and pay great heed to all the aspects of their judicial role.

Now, as decision-makers, we are primarily concerned with expressing our deeply felt opinions about a case. Judges in Canada have always been fiercely independent. Even Chief Justice Anglin recognized this, and in formulating the Court policy of one written opinion per judgment, he did not want to be understood as depriving in any way the members of the Court from the freedom of expressing their personal views. He said:

Then in regard to the opinions of the concurring majority, I further suggested that any member of the Court who felt that the conclusions of the majority could be better put, or better sustained, on some other ground than that which had been taken by the judge writing for them, would be at perfect liberty to add to the judgment his view, confining it, of course, to the matter necessary to make clear the ground on which he might think the judgment could be better supported.

I do not think that any Chief Justice would take issue with these words, even though these words might lead one to believe that aiming at one written opinion per judgment while at the same time maintaining each judge's ability to write separate opinions is an attempt to have one's cake and eat it too.

A compounding problem results from the occasional friction between the judges' individual view of the law and the necessity for the Court to function as a unit. There is no secret here. On some matters, and usually in the most important cases, there are strong pressures on the Court to speak collectively, to send a strong message. This may be the case, for example, when a specific provision of the Charter comes up to the Court for the first time, or when we are asked to dispose of a hotly-disputed issue involving close public attention. In such cases, there may be some pressure for an unanimous judgment from the Court. Compromises are made for that purpose. However, strong views cannot always be accommodated in an unanimous opinion. This is particularly so in Charter-related cases where there are no precedents, and the issues sometimes involve matters of great personal significance.

Here again it would be wrong to think that a judgment containing a plurality of opinions is necessarily a failure. As a court we sometimes have to allow new arguments to be distilled and gradually come to be accepted by the community. The successful adoption of a particular doctrine may take years, and many visits to the Court. Particularly with respect to constitutional questions, there are sometimes extremely compelling reasons to delay the resolution of an issue and to make sure that every aspect of a problem is given a chance to be explored before being assigned its place in the main body, or in the footnote, of legal textbooks. In such a context the expression of a diversity of points of view is part of the process of eventually arriving at a persuasive conclusion.

The occasional release of lengthy judgments and pluralistic opinions can thus be seen as a product of the internal dynamics of our Supreme Court, and serves 
to reflect the different expectations of the legal community as regards the role of the judiciary. As judges are accustomed to making the necessary adjustments, I feel authorized to draw a number of optimistic conclusions with respect to the conciseness and simplicity of our Supreme Court opinions.

\section{CONCLUSIONS}

Conclusion Number One: Overly long and complex judgments are the exception, not the rule.

The Supreme Court's judgments can at times seem interminable, but more often than not, this is not the case. While on occasion we can be "fractious", very often we all rally under the opinion of a single member the Court, and, other than in the cases where a dissenting point of view is expressed, only infrequently does a judgment contain more than two written opinions.

A close look at the last five years, so as to include all of the Charter cases, indicates that approximately four times out of five the Court's written judgments are unanimous. Also apparent is that approximately four times out of five the majority position is contained in a single judgment. Furthermore, the average length of the Court's judgments during that period is approximately twenty pages in the law reports. This is not a crisis situation.

Conclusion Number Two: Long and complex judgments are sometimes a necessary step in the development of the law.

This is simply restating my point that it will take time before we come to grips with our new constitutional document, and until we do, the preferable approach is to allow all views to be expressed, thereby hampering as little as possible our freedom to later expand or correct the courses we have chosen. To pursue the metaphor of the "dialogue", our legal community is one in which it is useful to allow many voices to participate early in the dialogue, whenever possible.

Conclusion Number Three: The Bar, jurists and university professors, as well as lower court judges, are instrumental in helping the Court make the necessary adjustments.

My favorite example is $R$. v. Therens. Taken in isolation, this case appears to be a true imbroglio. The primary set of reasons was given by Justice Le Dain. Nobody concurred with him on the result except Justice McIntyre, who gave reasons expanding a bit further on the s.24(2) issue. Chief Justice Dickson agreed with Justice Le Dain throughout except on the s.24(2) issue, with respect to which he agreed with Justice Lamer, who gave reasons agreeing with Justice Le Dain except on the s.24(2) issue, as I just said, but also in respect of s.1, on which point Justice Lamer ended up being alone. Finally Justice Estey gave reasons for himself as well as Justices Beetz, Chouinard and Wilson, agreeing in essence with Justice Le Dain's analysis, but differing strongly with him on the disposition of the case.

A roadmap is required to read this case. Yet, after instructive case comments by court observers, repeated arguments made in lower courts by able counsel, and subsequent decisions by learned judges, Therens ${ }^{5}$ has been distilled down to a few clear propositions of law, not the least of which is a crisp definition 
of "detention" under the Charter. A process of dialogue between all members of the community has successfully made Therens intelligible.

Finally, to those involved in the aforementioned dialogue who were good enough to make sense out of Therens, would you be so kind as to do the same with Dolphin Delivery ${ }^{6}$ and all the others. 